\title{
Pengaruh Pertumbuhan Ekonomi dan Dependency Ratio terhadap Tingkat Kemiskinan di Provinsi Jawa Barat Tahun 2000-2019
}

\author{
Nurhafizah*, Ade Yunita Mafruhat \\ Prodi Ilmu Ekonomi, Fakultas Ekonomi dan Bisnis, Universitas Islam \\ Bandung, Indonesia. \\ *emailnur2th@gmail.com, ade.yunita.mafruhat@unisba.ac.id
}

\begin{abstract}
This study aims to determine the effect of economic growth and dependency ratio on poverty levels in West Java Province in the long term and short term. In the trickle-down effect theory, it is stated that poverty is influenced by economic growth. While in the population cycle theory, poverty is influenced by the dependency ratio. The method used in this research is a quantitative approach method with time series data. The type of data used in this study is secondary data sourced from the Central Statistics Agency (BPS). The analytical method used in this study is the Vector Error Correction Model (VECM). The results show that in the long term economic growth has a positive effect on the poverty level in West Java, amounting to $0.319797 \%$ and the dependency ratio has a positive effect on the poverty level in West Java Province, amounting to $0.323306 \%$. Meanwhile, in the short term, economic growth has a positive effect on the poverty level of West Java Province in the previous two years of $0.241979 \%$ and the dependency ratio has an effect on the poverty level of West Java Province in the previous year of $0.323738 \%$. Poverty responses fluctuate to economic growth shocks and dependency ratios. The average contribution to the dependency ratio is $29.89 \%$. while the average contribution to economic growth is $6.79 \%$.
\end{abstract}

Keywords: Poverty, Economic Growth, Dependency Ratio, Trickle-Down Effect, Population Cycle.

\begin{abstract}
Abstrak. Penelitian ini bertujuan untuk mengetahui pengaruh pertumbuhan ekonomi dan dependency ratio terhadap tingkat kemiskinan di Provinsi Jawa Barat dalam jangka panjang dan jangka pendek. Dalam teori trickle-down effect dinyatakan bahwa kemiskinan dipengaruhi oleh pertumbuhan ekonomi. Sementara dalam teori siklus populasi, kemiskinan dipengaruhi oleh dependency ratio. Metode yang digunakan dalam penelitian yaitu metode pendekatan kuantitatif dengan data time series. Jenis data yang digunakan dalam penelitian ini yaitu data sekunder yang bersumber dari Badan Pusat Statistik (BPS). Metode analisis yang digunakan dalam penelitian ini yaitu Vector Error Correction Model (VECM). Hasil penelitian menunjukkan bahwa dalam jangka panjang pertumbuhan ekonomi berpengaruh positif terhadap tingkat kemiskinan di Jawa Barat, sebesar 0,319797\% dan dependency ratio berpengaruh positif terhadap tingkat kemiskinan di Provinsi Jawa Barat, sebesar 0,323306\%. Sementara dalam jangka pendek pertumbuhan ekonomi berpengaruh positif terhadap tingkat kemiskinan Provinsi Jawa Barat pada dua tahun sebelumnya sebesar 0,241979\% dan dependency ratio berpengaruh terhadap tingkat kemiskinan di Provinsi Jawa Barat pada satu tahun sebelumnya sebesar 0,323738\%. Respon kemiskinan berfluktuatif terhadap shock pertumbuhan ekonomi dan dependency ratio. Kontribusi pada dependency ratio rata-rata sebesar $29,89 \%$. sedangkan pada pertumbuhan ekonomi rata-rata kontribusinya sebesar 6,79\%.
\end{abstract}

Kata Kunci: Tingkat Kemiskinan, Pertumbuhan Ekonomi, Dependency Ratio, Trickle-Down Effect, Siklus Populasi. 


\section{A. Pendahuluan}

Salah satu syarat terciptanya kesejahteraan penduduk di suatu wilayah yakni dengan melakukan pembangunan di wilayah tersebut (Frisdiantara \& Mukhlis, 2018). Untuk mencapai keberhasilan pembangunan, maka dalam prosesnya harus menyelesaikan berbagai masalah pembangunan. Salah satu permasalahan inti dari pembangunan yakni kemiskinan (Digdowiseiso, 2019). Upaya yang dilakukan oleh Perserikatan Bangsa-Bangsa (PBB) dalam rangka pengentasan kemiskinan yakni dengan mengesahkan agenda Millennium Development Goals (MDGs) dan Sustainable Development Goals (SDGs). Pada kedua agenda tersebut telah ditetapkan kemiskinan sebagai tujuan nomor pertama. Hal ini menandakan kemiskinan menjadi permasalahan utama baik di negara maju maupun di negara berkembang yang harus diselesaikan. Todaro \& Smith (2015) menyatakan bahwa kemiskinan yang terjadi di negara berkembang cenderung lebih tinggi dibandingkan dengan kemiskinan di negara maju.

Indonesia sebagai negara berkembang pada periode 2000-2019 memiliki ratarata jumlah masyarakat miskin sebanyak 32,41 juta jiwa atau sebesar 14,06\%. Lebih jelasnya untuk melihat perkembangan kemiskinan di Indonesia pada periode 2000-2019 dapat dilihat pada Gambar 1.

Gambar 1.Perbandingan Jumlah Penduduk Miskin dan Persentase Kemiskinan di Indonesia Tahun 2000-2019

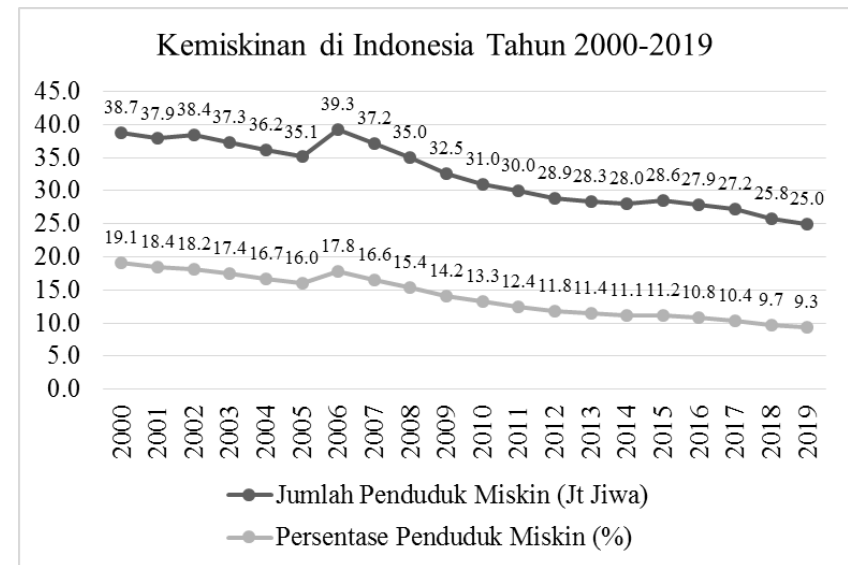

Sumber: Badan Pusat Statistik Indonesia

Terlihat pada Gambar 1 tingkat kemiskinan di Indonesia cukup tinggi. Hal ini karena rata-rata tingkat kemiskinan di Indonesia di atas 10\%, sehingga posisinya berada di level hard core poverty atau berada di level yang tinggi (Wahyudi \& Rejekingsih, 2013). Tingginya angka kemiskinan di Indonesia, kemudian menjadi program prioritas pemerintah Indonesia yang dicantumkan dalam dokumen utama pembangunan Indonesia (Nawacita). Dalam (Nawacita) program-program pengentasan kemiskinan yang ada, mengacu pada agenda SDGS.

Jika dilihat per-provinsi, terdapat tiga provinsi dengan penyumbang kemiskinan terbesar di Indonesia pada periode 2000-2019. Pertama, Provinsi Jawa Timur; Kedua, Provinsi Jawa Tengah; Ketiga, Provinsi Jawa Barat. Untuk lebih jelasnya terkait jumlah penduduk miskin dan persentase penduduk miskin di ketiga provinsi ini dapat dilihat pada Tabel 1

Tabel 1. Perbandingan Rata-rata Jumlah Penduduk Miskin dan Rata-rata Persentase Kemiskinan di Provinsi Jawa Timur, Provinsi Jawa Tengah dan Provinsi Jawa Barat Tahun 2000-2019 


\begin{tabular}{|c|c|c|}
\hline Provinsi & Kategori & $\begin{array}{c}\text { Rata- } \\
\text { Rata }\end{array}$ \\
\hline \multirow{2}{*}{$\begin{array}{c}\text { Jawa } \\
\text { Timur }\end{array}$} & Jumlah Penduduk Miskin (Juta Jiwa) & 6.04 \\
\cline { 2 - 3 } & Persentase Penduduk Miskin (\%) & 12.37 \\
\hline Jawa & Jumlah Penduduk Miskin (Juta Jiwa) & 5.62 \\
\cline { 2 - 3 } Tengah & Persentase Penduduk Miskin (\%) & 11.42 \\
\hline Jawa & Jumlah Penduduk Miskin (Juta Jiwa) & 4.77 \\
\cline { 2 - 3 } Barat & Persentase Penduduk Miskin (\%) & 11.33 \\
\hline
\end{tabular}

Sumber: Badan Pusat Statistik Indonesia

Pada Tabel 1 terlihat bahwa Provinsi Jawa Barat merupakan provinsi dengan rata-rata jumlah penduduk miskin terendah dibandingkan kedua provinsi lainnya. Namun sayangnya, jika dilihat dari kecepatan penurunan penduduk miskin, Provinsi Jawa Barat justru termasuk dalam provinsi yang paling lambat kecepatan penurunan kemiskinan dibandingkan dua provinsi lainnya. Kecepatan penurunan kemiskinan di Provinsi Jawa Barat hanya sebesar 8,49\%, lebih lambat dibandingkan Provinsi Jawa Timur (12,40\%) dan Provinsi Jawa Tengah (10,36\%).

Pada teori ekonomi pembangunan disebutkan bahwa pertumbuhan ekonomi merupakan variabel yang dapat mengurangi angka kemiskinan. Hubungan pertumbuhan ekonomi dengan kemiskinan ini dijelaskan dalam teori trickle-down effect atau teori tetesan ke bawah. Teori ini menjelaskan bahwa manfaat pertumbuhan ekonomi dapat dirasakan oleh penduduk miskin melalui penduduk kaya, sehingga hubungan pertumbuhan ekonomi dan kemiskinan memiliki hubungan negatif dan vertikal (Pangiuk, 2018). Sementara itu, dalam teori siklus populasi dinyatakan bahwa penyebab kemiskinan yakni karena adanya lonjakan pertumbuhan penduduk. Menurut Todaro \& Smith (2015), pertumbuhan penduduk yang tinggi dapat meningkatkan angka beban ketergantungan yang pada akhirnya berdampak pada peningkatan kemiskinan. Di Provinsi Jawa Barat pada periode 2000-2019 tingkat kemiskinan, pertumbuhan ekonomi, dan dependency ratio memiliki trend yang berfluktuatif. Untuk lebih jelasanya dapat dilihat pada Gambar 2 berikut.

Gambar 2. Perbandingan Tingkat Kemiskinan, Pertumbuhan Ekonomi dan Dependency Ratio Jawa Barat Tahun 2000-2019

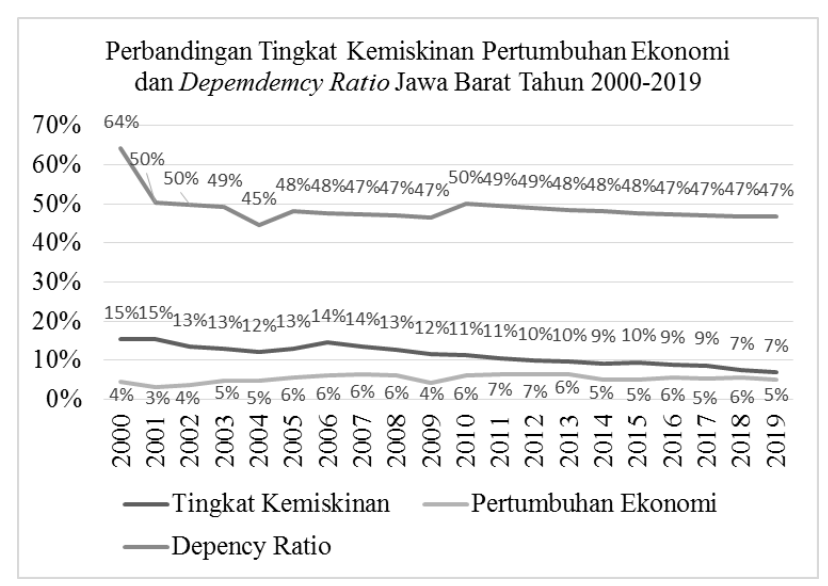

Sumber: Badan Pusat Statistik

Berdasarkan Gambar 2 terlihat bahwa tingkat kemiskinan memiliki tiga periode. Periode pertama terjadi tahun 2000-2004 trend-nya cenderung menurun. Pada periode kedua terjadi tahun 2004-2006 trend-nya cenderung meningkat. Periode ketiga terjadi tahun 2007-2019 menunjukkan trend yang cenderung menurun. Sedangkan pada JRIEB is licensed under Creative Commons Attribution- 
pertumbuhan ekonomi tiap tahunnya selalu berfluktuasi. Pada dependency ratio memiliki dua periode. Periode pertama terjadi tahun 2000-2010 trend-nya berfluktusif. Periode kedua terjadi tahun 2011-2019 trend-nya menurun, tetapi penurunannya mengalami penuyusutan tiap tahunya dengan rata-rata $0,37 \%$.

Adapun tujuan dari penelitian ini sebagai berkut:.

1. Teridentifikasinya pengaruh pertumbuhan ekonomi dan dependency ratio terhadap kemiskinan di Provinsi Jawa Barat tahun 2000-2019 dalam jangka pendek dan dalam jangka panjang.

2. Teridentifikasinya besaran pengaruh pertumbuhan ekonomi dan dependency ratio terhadap kemiskinan di Provinsi Jawa Barat tahun 2000-2019 dalam jangka pendek dan dalam jangka panjang.

3. Teridentifikasinya respon tingkat kemiskinan ketika terjadi shock padal pertumbuhan ekonomi dan dependency ratio sepuluh periode mendatang.

4. Teridentifikasinya kontribusi pertumbuhan ekonomi dan dependency ratio terhadap tingkat kemiskinan sepuluh periode mendatang.

\section{B. Metodologi Penelitian}

Metode yang digunakan dalam penelitian ini yaitu penelitian kuantitatif. Penelitian kuantitatif yaitu metode yang sejak awal hingga ke desain penelitiannya dilakukan secara sistematis, tersusun, dan terstruktur secara jelas (Sandu \& Sodik, 2015).

Jenis data yang digunakan dalam penelitian ini yaitu data sekunder, data sekunder merupakan data yang diperoleh dari sumber-sumber yang telah ada sebelumnya (Sandu \& Sodik, 2015). Sumber data yang diambil dalam penelitian ini yaitu melalui Badan Pusat Statistik Indonesia (BPS) dan Badan Pusat Statistik Provinsi Jawa Barat. Adapun data yang digunakan dalam peneliyian ini diantaranya betikut: pertama, data persentase tingkat kemiskinan Provinsi Jawa Barat tahun 2000-2019; keuda, data pertumbuhan ekonomi Provinsi Jawa Barat tahun 2000-2019; ketiga, data angka ketergantungan Provinsi Jawa Barat tahun 2000-2019.

Metode analisis yang digunakan dalam penelitian ini yaitu Vector Error Correction Model (VECM). Metode VECM merupakan metode turunan dari VAR, atau sering disebut VAR yang terintrinsik. VECM ini digunakan pada variabel yang tidak staioner tetapi memiliki peluang terkointegrasi (Firdaus, 2019).

\section{Hasil Penelitian dan Pembahasan}

Hasil dan Pembahsan dari penelitian ini dapat dilihat pada pembahasan berikut.

\section{Hubungan Jangka Pendek dan Jangka Panjang antara Pertumbuhan Ekonomi dan Tingkat Kemiskinan}

Estimasi VECM dilakukan untuk mengidentifikasi hubungan jangka pendek dan jangka panjang variabel dalam model. Hipotesis yang di gunakan dalam pada uji VECM yaitu, Ho ditolak jika t-statistik > t-tabel dan Ho diterima jika t-statistik < t-tabel. Sebelum membahas hasil estimasi VECM, terlebih dahulu dilakukan perhitungan t-tabel, dari hasil perhitungan t-tabel didapatkan angka 2.178813.

Tabel 2. Hasil Estimasi Jangka Pendek dan Jangka Panjang Pertumbuhan Ekonomi

\begin{tabular}{|c|c|c|}
\hline Variabel & Koefisien & t-Statistic \\
\hline \multicolumn{3}{|c|}{ Jangka Panjang } \\
\hline $\begin{array}{l}\text { D(PERTUMBUHAN } \\
\text { EKONOMI(-1)) }\end{array}$ & 0.319797 & 2.55689 \\
\hline
\end{tabular}




\begin{tabular}{|c|c|c|}
\hline Variabel & Koefisien & t-Statistic \\
\hline \multicolumn{3}{|c|}{ Jangka Pendek } \\
\hline $\begin{array}{l}\text { D(PERTUMBUHAN } \\
\text { EKONOMI(-1),2) }\end{array}$ & 0.19376 & 1.95938 \\
\hline $\begin{array}{l}\text { D(PERTUMBUHAN } \\
\text { EKONOMI(-2),2) }\end{array}$ & 0.241979 & 2.5388 \\
\hline
\end{tabular}

Sumber: Data Olahan Eviews 10

Pada Tabel 2 menunjukkan hasil uji VECM jangka pendek pada variabel pertumbuhan ekonomi pada dua tahun sebelumnya menunjukkan Ho yang ditolak, dimana $2.53880>2.178813$ dengan koefisien 0,241979. Maka setiap kenaikan pertumbuhan ekonomi $1 \%$ pada dua tahun sebelumnya berpengaruh terhadap kenaikan tingkat kemiskinan saat ini sebesar $0.241979 \%$. sementara itu, pada estimasi jangka panjang menunjukkan hasil $2.55689>2.178813$ dengan koefisien 0,319797. Dengan demikian setiap kenaikan pertumbuhan ekonomi sebesar $1 \%$ berpengaruh terhadap kenaikan tingkat kemiskinan sebesar $0.319797 \%$ dan begitupun sebaliknya.

Hasil penelitian ini bertentangan dengan teori trickle-down effect, yang menyatakan pertumbuhan ekonomi berpengaruh negatif terhadap kemiskinan. Hasil penelitian ini sesuai dengan pernyataan World Bank (2006) yang menyatakan bahwa pertumbuhan ekonomi tidak dapat mengurangi kemiskinan di Indonesia. Hal ini dikarenakan sajak tahun 1998 pertumbuhan ekonomi di Indonesia distribusinya kurang merata. Serupa dengan temuan world bank penelitian yang dilakukan oleh Ishak et al (2020), menyatakan bahwa pertumbuhan ekonomi berpengaruh positif dan signifikan terhadap kemiskinan di Kota Makassar. Dikatakan bahwa pertumbuhan ekonomi mempengaruhi kemiskinan karena pendistibusiannya tidak merata dan pemerintah hanya fokus pada percepatan peningkatan perekonomiannya saja. Penelitian yang dilakukan

Pada kasus Provinsi Jawa Barat, terlihat pada rata-rata gini ratio-nya antara tahun 2007-2019 sebesar 0,39\%. Menurut Todaro \& Smith (2015), angka tersebut tidak termasuk kedalam gini ratio yang tinggi dan tidak termasuk ke gini ratio yang rendah. Meskipun gini ratio Provinsi Jawa Barat tidak termasuk tinggi, namun gini ratio Provinsi Jawa Barat antara periode 2007-2019 periode menunjukkan trend yang cenderung meningkat. Jika dibandingkan awal periode dengan akhir periode. Terlihat tahun 2007 gini ratio Provinsi Jawa Barat sebesar 0.357, tahun 2019 gini rationya meningkat menjadi 0,402. Dengan demikian dapat dikatakan bahwa manfaat pertumbuhan ekonomi di Provinsi Jawa Barat distribusinya belum merata dan masih dirasakan segelintir orang saja. Jadi dengan adanya peningkatan pertumbuhan ekonomi justru membuat ketimpangan pendapatan semakin melebar. Dengan demikian pertumbuhan ekonomi berdampak terhadap kenaikan kemiskinan.

\section{Hubungan Jangka Pendek dan Jangka Panjang Dependency Ratio dan Tingkat Kemiskinan}

Tabel 3. Hasil Estimasi Jangka Pendek dan Jangka Panjang Dependency Ratio

\begin{tabular}{|c|c|c|}
\hline Variabel & Koefisien & t-Statistic \\
\hline \multicolumn{3}{|c|}{ Jangka Panjang } \\
\hline $\mathrm{D}(D E P E N D E N C Y$ RATIO(-1)) & 0.32331 & 6.39127 \\
\hline \multicolumn{3}{|c|}{ Jangka Pendek } \\
\hline $\begin{array}{l}\mathrm{D}\left(D E P E N D E N C Y \_R A T I O(-\right. \\
1), 2)\end{array}$ & 0.323738 & 5.26567 \\
\hline $\begin{array}{l}\mathrm{D}\left(D E P E N D E N C Y \_R A T I O(-\right. \\
2), 2)\end{array}$ & -0.05703 & -1.571 \\
\hline
\end{tabular}

JRIEB is licensed under Creative Commons Attribution- 
Sumber: Data Olahan Eviews 10

Berdasarkan Tabel 2 terlihat bahwa variabel dependency ratio pada satu tahun sebelumnya menunjukkan hasil Ho yang ditolak, dimana $5.26567>2.178813$. Maka setiap kenaikan dependency ratio $1 \%$ pada satu tahun sebelumnya berpengaruh terhadap kenaikan tingkat kemiskinan saat ini sebesar $0.323738 \%$. Pada estimasi jangka panjang juga menunjukkan hasil Ho yang ditolak dimana $6.39127>2.178813$ dengan koefisien sebesar 0,32306, sehingga setiap kenaikan dependency ratio sebesar $1 \%$ berdampak pada kenaikan tingkat kemiskinan sebesar $0.323306 \%$, dan begitupun sebaliknya.

Hasil penelitian ini sesuai dengan teori siklus populasi. Hal ini berarti bahwa teori siklus populasi terjadi pada Provinsi Jawa Barat dalam jangka panjang dan dalam jangka pendek satu tahun sebelumnya. Adanya dependency ratio seperti yang dijelaskan teori siklus kemiskinan dapat menyebabkan berkurangnya tingkat tabungan dan investasi. Berkurangnya tabungan dan investasi dapat berdampak pada produktivitas yang turun. Hal ini dapat membentuk pengangguran dan kemiskinan semakin tinggi. Oleh karena itu, kenaikan dependency ratio berpengaruh terhadap kenaikan kemiskinan.

Hasil penelitian ini sesuai dengan penelitian yang dilakukan oleh Ginting et al. (2020) dilakukan dengan judul "The Effect of Education and Dependency Ratio on Economic Growth and Poverty in Papua". Menyatakan bahwa dependency ratio berpengaruh positif dan signifikan terhadap kemiskinan di Provinsi Papua, hal ini dikarenakan penduduk produktif harus menanggung beban penduduk yang tidak produktif. Penelitian yang dilakukan oleh Rohana et al. (2017) yang meneliti kemiskinan di Kabupaten Sarolangun menyatakan bahwa kemiskinan Kabupaten Sarlangun dipengaruhi oleh dependency ratio secara positif dan signifikan.

\section{Respon Tingkat Kemiskinan ketika terjadi Shock Pertumbuhan Ekonomi dan Dependency Ratio}

Gambar 3. Impluse Response Tingkat Kemiskinan Terhadap Shock Pertumbuhan Ekonomi

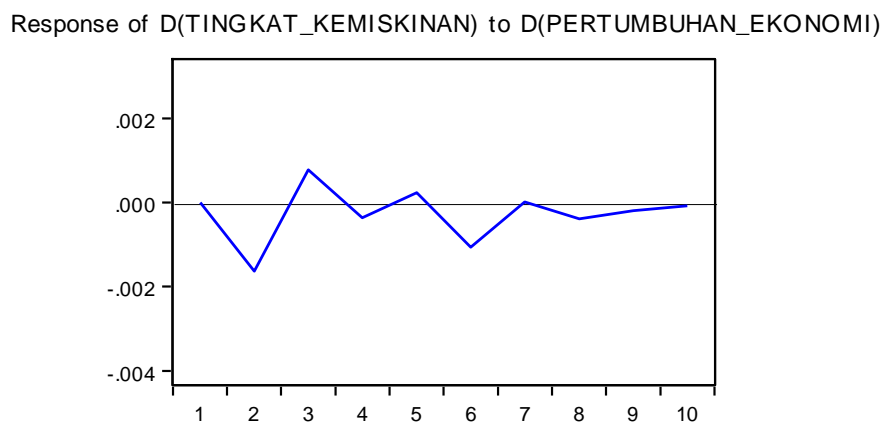

Sumber: Data Olahan Eviews 10

Pada Gambar 3 menunjukkan ketika terjadi shock pada pertumbuhan ekonomi, respon yang ditampilkan tingkat kemiskinan selama sepuluh periode mendatang cenderung negatif. Pada awal periode, tingkat kemiskinan tidak menunjukkan respon akibat adanya shock pada pertumbuhan ekonomi. Periode ke 2-6 respon tingkat kemiskinan cukup berfluktuatif Selanjutnya periode ke 7-10 menunjukkan respon yang mulai stabil. Respon ini menunjukkan kemiskinan sepuluh periode mendatang tidak stabil dan menunjukkan respon yang cenderung negatif akibat adanya shock pada pertumbuhan ekonomi. Kemudian respon tingkat kemiskinan akibat adanya shock pada dependency ratio dapat dilihat pada Gambar 4. 
Gambar 4. Impluse Response Tingkat Kemiskinan Terhadap Shock Dependency Ratio

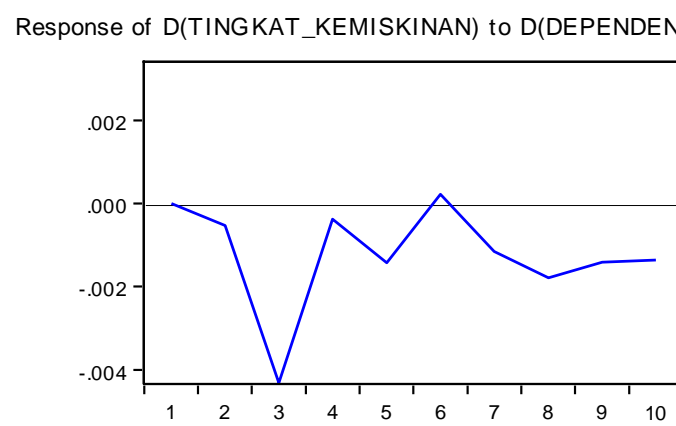

Sumber: Data Olahan Eviews 10

Pada Gambar 4, menunjukkan bahwa ketika dependency ratio mengalami shock, respon yang ditampilkan tingkat kemiskinan selama sepuluh periode mendatang cenderung negatif. Pada periode pertama tingkat kemiskinan belum menunjukkan respon. Respon tingkat kemiskinan pada seluruh periode respon tingkat kemiskinan cukup berfluktuatif. Tetapi pada periode 7-10 respon tingkat kemiskinan mulai stabil. Respon negatif kemiskinan ini menunjukkan ketika shock dependency ratio meningkat kemiskinan menunjukkan respon yang menurun.

\section{Kontribusi Pertumbuhan Ekonomi dan Dependency Ratio terhadap Tingkat Kemiskinan}

Tabel 4. Hasil Variance Decompotition

\begin{tabular}{|c|c|c|c|c|}
\hline Period & S.E. & $\begin{array}{c}\text { D(TING } \\
\text { KAT_KE } \\
\text { MISKIN } \\
\text { AN) }\end{array}$ & $\begin{array}{c}\text { D(PERT } \\
\text { UMBUH } \\
\text { AN_EKO } \\
\text { NOMI) }\end{array}$ & $\begin{array}{c}\text { D(DEPE } \\
\text { NDENC } \\
\text { Y_RATI } \\
\text { O) }\end{array}$ \\
\hline 1 & 0.0034 & 100.000 & 0.000 & 0.000 \\
\hline 2 & 0.0044 & 84.858 & 13.744 & 1.398 \\
\hline 3 & 0.0070 & 55.118 & 6.644 & 38.238 \\
\hline 4 & 0.0071 & 55.096 & 6.822 & 38.082 \\
\hline 5 & 0.0073 & 54.146 & 6.485 & 39.369 \\
\hline 6 & 0.0076 & 55.570 & 7.942 & 36.488 \\
\hline 7 & 0.0079 & 57.074 & 7.298 & 35.628 \\
\hline 8 & 0.0085 & 57.657 & 6.610 & 35.733 \\
\hline 9 & 0.0087 & 57.079 & 6.329 & 36.592 \\
\hline 10 & 0.0089 & 56.537 & 6.070 & 37.393 \\
\hline
\end{tabular}

Sumber: Data Olahan Eviews 10

Pada Tabel 4, menunjukkan bahwa kontribusi terbesar yang mempengaruhi tingkat kemiskinan selama sepuluh periode mendatang yaitu dari dirinya sendiri. Kontribusi tertingginya terjadi di periode ke-1 yaitu sebesar $100 \%$, hal ini terjadi karena pada periode ke-1 variabel pertumbuhan ekonomi dan dependency ratio belum memiliki pengaruh terhadap variabel tingkat kemiskinan dan kontribusi terendahnya terjadi pada periode ke-10 yaitu sebesar 56,53\%. Kontribusi selanjutnya yang mempengaruhi tingkat kemiskinan berasal dari dependency ratio, kontribusi tertingginya terjadi pada period eke-3 yaitu sebesar 38,23\% dan rata-rata kontribusinya selama sepuluh periode mendatang sebesar 28,89\%.. Kontribusi paling kecil terhadap tingkat kemiskinan terjadi pada variabel pertumbuhan ekonomi, kontribusi tersebarnya terjadi di periode ke-2 yaitu sebesar $13,74 \%$ dan rata-rata kontribusinya selama sepuluh periode mendatang yaitu sebesar $6,97 \%$. 


\section{Kesimpulan}

Berdasarkan pembahasan dalam penelitian ini, peneliti menyimpulkan beberapa hasil penelitian sebagai berikut:

1. Hasil estimasi jangka panjang pertumbuhan ekonomi berpengaruh positif terhadap tingkat kemiskinan di Provinsi Jawa Barat yaitu sebesar 0.319797\%. Dalam jangka pendek pada satu tahun sebelumnya pertumbuhan ekonomi tidak berpengaruh terhadap tingkat kemiskinan Provinsi Jawa Barat dan pada dua tahun sebelumnya pertumbuhan ekonomi berpengaruh secara positif terhadap tingkat kemiskinan di Provinsi Jawa Barat yaitu sebesar $0.241979 \%$.

2. Hasil estimasi jangka panjang dependency ratio berpengaruh positif terhadap tingkat kemiskinan di Provinsi Jawa Barat yaitu sebesar $0.323306 \%$. Dalam jangka pendek pada satu tahun sebelumnya dependency ratio berpengaruh positif terhadap tingkat kemiskinan Provinsi Jawa Barat yaitu sebesar $0.323738 \%$ dan pada dua tahun sebelumnya dependency ratio tidak berpengaruh terhadap tingkat kemiskinan di Provinsi Jawa Barat.

3. Hasil analisis impulse response menunjukkan respon tingkat kemiskinan akibat adanya shock, pada pertumbuhan ekonomi selama sepuluh periode mendatang menunjukkan respon yang cenderung negatif dan berfluktuatif. Serupa dengan pertumbuhan ekonomi, hasil analisis impulse response tingkat kemiskinan akibat adanya shock pada dependency ratio selama sepuluh periode mendatang menunjukkan respon yang cenderung negatif dan berfluktuatif.

4. Hasil analisis variance decomposition sepuluh periode mendatang, menunjukkan bahwa kontribusi pertumbuhan ekonomi terhadap tingkat kemiskinan rata-rata kontribusi-nya sebesar $6,97 \%$. Pada dependency ratio kontribusi-nya terhadap tingkat kemiskinan yaitu sebesar $28,89 \%$.

\section{Acknowledge}

Peneliti mengucapkan rasa terima kasih yang sebesar-besarnya kepada seluruh pihak yang telah membantu dalam penyelesaian penelitian ini. Khususnya kepada kedua pembimbing peneliti yaitu ibu Ade Yunita Mafruhat, SE., M.SOC.SC, sebagi pembimbing pertama peneliti dan kepada bapak Meidy Haviz, SE., M.Si, selaku pembimbing kedua peneliti.

\section{Daftar Pustaka}

[1] Digdowiseiso, K. (2019). Teori pembangunan. Katalog Dalam terbitan (KDT).

[2] Firdaus, M. (2019). Aplikasi Ekonomietrika Untuk Data Panel dan Time Series. IPB Press.

[3] Frisdiantara, C., \& Mukhlis, I. (2018). Ekonomi Pembangunan Sebuah Teoritis dab Empiris. Deepublish.I

[4] Ginting, T. A. B., Sudibia, I. K., Dewi, N. P. M., \& Marhaeni, A. A. I. N. (2020). The Effect of Education and Dependency Ratio on Economic Growth and Poverty in Papua. American Journal of Humanities and Social Sciences Research (AJHSSR), 4(6), 186-195.

[5] Ishak, R. A., Zakaria, J., \& Arifin, M. (2020). Pengaruh Pertumbuhan Ekonomi, Pendidikan dan Pengangguran Terhadap Tingkat Kemiskinan di Kota Makassar Author. PARADOKS: Jurnal Ilmu Ekonomi Vol., 3(2), 41-53.

[6] Pangiuk, A. (2018). Pengaruh Pertumbuhan Ekonomi Terhadap Penurunan Kemiskinan di Provinsi Jambi Tahun 2009-2013. Iltizam Journal Of Shariah Economic Research, 2(2), 4466.

[7] Rohana, Junaidi, \& Prihanto, P. H. (2017). Analisis Pengaruh Pertumbuhan Penduduk dan Rasio Ketergantungan Terhadap Kemiskinan di Kabupaten Sarolangun. E-Jurnal Ekonomi Sumberdaya Dan Lingkungan, 6(2), 69-79.

[8] Sandu, S., \& Sodik, A. (2015). Dasar Metodologi Penelitian. Literasi Media Publishing.

[9] Todaro, M. P., \& Smith, S. C. (2015). Economic Development (12th ed.). Pearson. 
[10] Wahyudi, D., \& Rejekingsih, T. W. (2013). Analisis Kemiskinan di Jawa Tengah. Diponegoro Journal of Economics, 2(1), 1-15.

[11] World Bank. (2006). Making the New Indonesia Work for the Poor. World Bank. 